\title{
Penerapan Metode Eksperimen Berbantu Puzzle Picture Untuk Meningkatkan Hasil Belajar Siswa Materi Organ Pernapasan Manusia
}

\section{Masrokhah}

SDN Bintoro 5 Demak, Jawa Tengah.

Email: masrokhah646@gmail.com

\section{Info Artikel Abstract}

Sejarah Artikel:

Diserahkan 08 Agustus 2021

Direvisi 26 November 2021

Disetujui 27 November 2021

\section{Keywords:}

experimental method,

puzzle picture.

learning outcomes

\begin{abstract}
This study aims to describe the application of the puzzle picture-assisted experimental method to improve the learning outcomes of the human breathing apparatus for grade $5 \mathrm{~A}$ students at SD Negeri Bintoro 5 in semester 1 of the 2019/2020 academic year.

This research is a Classroom Action Research (CAR) consisting of 2 cycles, each cycle through stages, namely: planning, implementing, observing, and reflecting. The subjects of this study were students of class 5 A SD Negeri Bintoro 5 Demak, totaling 38 students. Data collection techniques using test and observation techniques. The instruments used in data collection were in the form of evaluation test questions at the end of the cycle and observation sheets. Data analysis used quantitative and qualitative descriptive.

The results of the study showed that there was an increase in learning outcomes for human respiratory equipment through the application of the experimental method assisted by the puzzle picture media in 5A grade students of SD Negeri Bintoro 5 in the 2019/2020 school year. The increase in the average value of student learning outcomes from the pre-cycle of 58 to 69 in the first cycle and increased to 80 in the second cycle. The percentage of students' completeness also increased from 10 students (26\%) in the pre-cycle to 22 students (66\%) in the first cycle and 36 students (95\%) in the second cycle.
\end{abstract}

\begin{abstract}
Abstrak
Penilitian ini bertujuan untuk mendeskripsikan penerapan metode eksperimen berbantu puzzle picture untuk meningkatkan hasil belajar materi alat pernapasan manusia siswa kelas 5A di SD Negeri Bintoro 5 pada semester 1 tahun pelajaran 2019/2020.

Penelitian ini adalah Penelitian Tindakan Kelas (PTK) terdiri dari 2 siklus yang masingmasing siklus melalui tahapan yaitu: perencanaan, pelaksanaan, pengamatan, dan refleksi. Adapun subjek penelitian ini adalah siswa kelas 5A SD Negeri Bintoro 5 Demak yang berjumlah 38 siswa. Teknik pengumpulan data menggunakan teknik tes dan observasi. Instrumen yang digunakan dalam pengumpulan data berupa soal tes evaluasi diakhir siklus dan lembar observasi. Analisis data menggunakan deskriptif kuantitatif dan kualitatif. Hasil penelitian menunjukkan terdapat peningkatan hasil belajar materi alat pernapasan manusia melalui penerapan metode eksperimen berbantuan media puzzle picture pada siswa kelas 5A SD Negeri Bintoro 5 tahun pelajaran 2019/2020. Peningkatan nilai rata-rata hasil belajar siswa dari pra siklus sebesar 58 menjadi 69 pada siklus I dan meningkat menjadi 80 pada siklus II. Presentase ketuntasan siswa juga mengalami peningkatan dari 10 siswa (26\%) pada pra siklus menjadi 22 siswa (66\%) pada siklus I dan 36 siswa $(95 \%)$ pada siklus II.
\end{abstract}

(C) 2020 Universitas Muria Kudus 


\section{PENDAHULUAN}

Pendidikan merupakan upaya yang terorganisasi, berencana dan berlangsung secara terus menerus sepanjang hayat untuk membentuk manusia dewasa dan berbudaya. Bagi siswa, belajar merupakan sebuah proses interaksi antara siswa dengan guru, siswa dengan siswa lainnya, serta siswa dengan lingkungan. Proses pembelajaran dapat mengembangkan potensi siswa apabila guru memiliki pengetahuan dan kerangka pikir yang menyeluruh tentang sebuah proses pembelajaran. Pembelajaran haruslah merupakan bagian dari proses pemberdayaan diri siswa secara utuh dan harus mampu mendorong tumbuhnya keaktifan dan kreativitas optimal setiap siswa (Aunurrahman, 2010). Guru sudah seharusnya menggunakan metode pembelajaran yang tidak hanya membuat proses pembelajaran menjadi menarik, tetapi juga memberikan ruang bagi siswa untuk mengembangkan kreativitasnya, berimajinasi dan terlibat secara langsung dan aktif sepanjang proses pembelajaran.

Metode pembelajaran merupakan cara guru yang digunakan oleh guru dalam menyampaikan pesan pembelajaran kepada siswa dalam mencapai tujuan pembelajaran. Dengan memilih metode pembelajaran diharapkan pencapaian tujuan belajar dapat terpenuhi. Penggunaan metode yang tidak sesuai dengan karakteristik materi pembelajaran dapat menjadi kendala dalam pencapaian tujuan yang telah dirumuskan (Widayanti \& Slameto, 2016). Guru perlu melakukan pengkajian secara cermat dan berkesinambungan terhadap metode pembelajaran dan strateginya yang relevan. Pengkajian ulang metode tersebut akan lebih bermakna apabila guru dapat mempraktikkan penggunaannya dalam proses belajar mengajar sehari-hari (Syah, 2005). Selain itu, apabila guru secara berkesinambungan mengkaji metode pembelajaran yang digunakan juga dapat meningkatkan kualitas diri seorang guru.

Berdasarkan hasil observasi yang dilakukan di kelas 5A SD Negeri Bintoro 5 Demak diketahui bahwa pembelajaran yang berlangsung belum dapat mengembangkan kreativitas pemikiran dan memberikan pengalaman langsung kepada siswa. Proses pembelajaran IPA yang dilakukan pada materi alat pernapasan manusia lebih menekankan pada verbalisme dan kurang melibatkan siswa dalam proses pembelajaran. Pembelajaran tersebut menyebabkan siswa cepat merasa bosan dan kurang tertarik untuk mengikuti kegiatan pembelajaran yang sedang berlangsung. Hal ini tentu akan berakibat pada kurangnya pemahaman siswa terhadap materi pembelajaran yang disampaikan.
Hasil belajar IPA materi alat pernapasan manusia siswa kelas 5A SD Negeri Bintoro 5 Demak masih rendah. Hal ini dapat dilihat dari nilai rata-rata pada penilaian harian sebesar 58 . Terdapat 28 siswa yang nilainya masih dibawah nilai rata-rata dari jumlah seluruh siswa yaitu 38 siswa. Pada dasarnya sebagian siswa telah mendapatkan nilai di atas Kriteria Ketuntasan Minimal (KKM) yang telah ditentukan yaitu 70, namun ada sebanyak $26 \%$ dari jumlah siswa yang masih mendapatkan nilai di bawah KKM.

Berdasarkan hasil wawancara, beberapa siswa kelas 5A menyatakan bahwa materi alat pernapasan manusia sulit untuk dipahami dan kurang menyenangkan. Hal ini dikarenakan proses pembelajaran yang dilakukan siswa hanya sebatas teori dan hafalan sehingga keterlibatan siswa secara langsung dalam pembelajaran kurang. Siswa merasa kesulitan memahami materi sistem pernafasan karena materi bersifat abstrak terutama ketika membahas organ dalam pernafasan. Media pembelajaran yang digunakan hanya berupa gambar sehingga kurang terlihat nyata. Hal tersebut juga menyebabkan rendahnya pemahaman siswa yang berefek pada hasil belajar siswa.

Hasil refleksi dan evaluasi pembelajaran yang dilakukan oleh guru dan peneliti selama ini ada beberapa kemungkinan yang menyebabkan rendahnya hasil belajar siswa dalam mengikuti pembelajaran, yaitu dalam pembelajaran guru memberikan aktivitas belajar pada siswa yang sifatnya cenderung mencatat dan menghafal padahal aktivitas pembelajaran IPA akan lebih mudah diingat jika pembelajaran yang dilakukan oleh guru melibatkan siswa secara langsung, misalnya praktek dan ekperimen. Selain itu siswa kurang mampu memusatkan perhatian pada guru saat proses belajar berlangsung.

Salah satu upaya yang dapat dilakukan untuk mengatasi permasalahan tersebut adalah dengan menerapkan metode eksperimen. Metode eksperimen adalah metode pembelajaran yang memberikan kesempatan kepada siswa baik secara perorangan ataupun kelompok untuk melakukan suatu proses atau eksperimen dengan mengalami dan membuktikan sendiri sesuatu yang dipelajarinya (Sagala, 2010). Metode eksperimen dianggap sesuai untuk pembelajaran IPA karena mampu memberikan kondisi belajar yang dapat mengembangkan kemampuan berfikir dan kreativitas secara optimal (Juita, 2019). Hal ini dikarenakan dalam metode eksperimen siswa diberi kesempatan untuk menyusun sendiri konsep dalam struktur kognitifnya, sehingga nantinya mereka akan dapat mengaplikasikan konsep tersebut dalam kehidupan (Tarmizi dkk, 2011). Metode eksperimen ini dapat membuat 
siswa lebih percaya atas kebenaran atau kesimpulan berdasarkan percobaannya sendiri daripada hanya menerima kata guru atau buku (Hamdayana, 2017). Guru dapat mengembangkan keterlibatan siswa secara aktif selama proses pembelajaran baik itu fisik, mental, maupun emosional dalam metode eksperimen. Keterlibatan tersebut diharapkan akan dapat meningkatkan pemahaman siswa terhadap materi yang disampaikan, sehingga hasil belajar siswa juga akan meningkat. Metode eksperimen memberikan kesempatan kepada siswa untuk melatih keterampilan prosesnya sekaligus memberikan pengalaman secara langsung yang dapat tertanam dalam ingatannya agar memperoleh hasil belajar yang maksimal.

Penggunaan metode eksperimen juga diperlukan media pembelajaran yang tepat. Media yang dapat diterapkan pada karakteristik materi sistem pernaasan manusia adalah media puzzle picture. Puzzle adalah permainan klasik bukan asli dari Indonesia. Puzzle picture dapat membantu anak belajar memecahkan masalah. Dengan mencoba beberapa cara memasangkan kepingan berupa potongan-potongan gambar maka siswa dilatih untuk berpikir kreatif. Permainan puzzle picture juga mengasah ketekunan anak dalam memecahkan masalah, tentunya (Saraswati, 2014). Puzzle picture merupakan jenis permainan teka-teki menyusun potongan-potongan gambar. Septia, dkk (2015) menyatakan, dengan terbiasa bermain puzzle picture, lambat laun, mental anak juga terbiasa bersikap tenang, tekun, dan sabar dalam menyelesaikan sesuatu. Kepuasan yang didapat saat ia menyelesaikan puzzle picture pun merupakan salah satu pembangkit motivasi untuk mencoba hal-ha yang baru baginya. Bermain puzzle picture, selain menyenangkan, ternyata juga dapat meningkatkan keterampilan dan kecerdasan seorang anak

Penggunaan metode eksperimen berbantu media puzzle picture dapat menjadi suatu alternatif bagi guru untuk membangkitkan semangat belajar siswa yang kurang aktif dan menghilangkan kesan membosankan pada pelajaran IPA. Media puzzle picture dalam kegiatan pembelajaran IPA dapat menumbuhkan rasa ingin belajar dalam dirinya dan dapat menjadikan penilaian hasil belajar yang memuaskan.

Penerapan metode eksperimen telah terbukti dapat meningkatkan hasil belajar IPA yang dilakukan dalam penelitian sebelumnya diantaranya adalah penelitian Mupelita, G. (2019). Hasil penelitian menunjukkan bahwa kolaborasi media picture dengan metode eksperimen pada pelajaran biologi materi sistem pernapasan manusia dapat meningkatkan hasil belajar siswa kelas XI MIPA 3 di SMA Negeri 2 Pangkalpinang. Hasil penelitian Ermida, E. (2019) juga menunjukkan bahwa pembelajaran eksperimen memiliki dampak positif dalam meningkatkan prestasi belajar siswa. Kriteria keberhasilan yang telah ditetapkan peneliti tercapai pada siklus II yaitu persentase rata-rata skor hasil tes akhir meningkat dari 73\% menjadi $88 \%$.

Berdasarkan uraian tersebut, tujuan penelitian ini adalah mendeskripsikan penerapan metode eksperimen berbantu puzzle picture untuk meningkatkan hasil belajar materi alat pernapasan manusia siswa kelas $5 \mathrm{~A}$ di SD Negeri Bintoro 5 pada semester 1 tahun pelajaran 2019/2020.

\section{METODE PENELITIAN}

Jenis penelitian ini yang digunakan yaitu Penelitian Tindakan Kelas (PTK) dengan merujuk pada model Kemmis dan Mc. Taggart (dalam Sugiyono, 2014). Adapun model PTK yang digunakan meliputi empat langkah yaitu 1) Perencanaan; 2) pelaksanaan; 3) pengamatan; dan 4) Refleksi.

Subjek penelitian ini yaitu siswa kelas $5 \mathrm{~A}$ SDN Bintoro 5 Demak sebanyak 38 siswa dengan jumlah siswa 22 perempuan dan 16 siswa laki-laki. Penelitian dilaksanakan dalam 2 siklus dan masing-masing siklus terdiri dari 2 pertemuan. Siklus I dilaksanakan pada tanggal 28 Agustus 2019 dan siklus II pada tanggal 4 September 2019. Sedangkan obyek penelitian yang penulis gunakan adalah hasil belajar siswa pada mata pelajaran IPA dengan materi alat pernapasan manusia.

Teknik pengumpulan data menggunakan teknik tes dan nontes. Teknik tes melalui tes evaluasi belajar pada materi alat pernafasan manusia yang dilaksanakaan pada akhir siklus dalam bentuk tes esaay. Sedangkan teknik non tes dilakukan dengan teknik observasi dan menggunakan instrumen lembar observasi.

Analisis data menggunakan analisis deskriptif kuantitatif dan kualitatif. Indikator keberhasilan dalam penelitian ini adalah hasil belajar siswa dengan nilai ketuntasan diatas 75\% dari seluruh siswa. Sedangkan nilai Ketuntasan Belajar Minimal (KBM) adalah 70.

\section{HASIL DAN PEMBAHASAN}

\section{Deskripsi Kondisi Pra Siklus}

Pelaksanaan pembelajaran IPA materi alat pernapasan manusia yang dilakukan pada hari Senin, 19 Agustus 2019 diperoleh hasil penilaian harian masih banyak siswa yang 
mendapat nilai kurang dari KKM. Berikut ini tabel dari nilai penilaian harian sebelum pelaksanaan perbaikan pembelajaran (pra siklus).

Tabel 1 Hasil Penilaian Harian IPA Pra Siklus

\begin{tabular}{cccc}
\hline No. & Nilai (f) & Jumlah Siswa (x) & $\mathrm{fx}$ \\
\hline 1 & 40 & 4 & 160 \\
2 & 50 & 11 & 550 \\
3 & 60 & 13 & 780 \\
4 & 70 & 7 & 490 \\
5 & 80 & 3 & 240 \\
6 & 90 & 0 & 0 \\
7 & 100 & 0 & 0 \\
\hline \multicolumn{5}{c}{ Jumlah } & $\mathbf{3 8}$ & $\mathbf{2 2 2 0}$ \\
\hline \multicolumn{2}{c}{ Rata- rata } & & $\mathbf{5 8}$ \\
\hline \multicolumn{2}{c}{ Ketuntasan } & $\mathbf{1 0}$ & $\mathbf{2 6 \%}$ \\
\hline
\end{tabular}

Berdasarkan data tersebut dikeathui dari 38 siswa yang mendapat nilai diatas 70 hanya 10 siswa, selebihnya siswa mendapat nilai kurang dari KKM. Selanjutnya peneliti mengadakan perbaikan pembelajaran agar pembelajaran materi alat pernapasan manusia dapat meningkatkan hasil belajar siswa.

\section{Deskripsi Siklus I}

Pelaksanaan pembelajaran IPA materi alat pernapasan manusia dalam penelitian ini dilakukan dalam 2 siklus. Siklus I terdiri dari 4 tahap yaitu tahap perencanaan, pelaksanaan, observasi, dan refleksi. Kegiatan pada tahap perencanaan siklus I meliputi mengidentifikasi masalah, merancang perangkat pembelajaran, dan mengembangkan instrumen penilaian. Tahap pelaksanaan siklus I dilakukan pada hari Rabu, 28 Agustus 2019. Pelaksanaan pembelajaran siklus 1 sesuai dengan Rencana Pelaksanaan Pembelajaran (RPP) Siklus I. Kegiatan pembelajaran ini diakhiri dengan mengerjakan soal tes, pada kegiatan penutup dengan tujuan untuk mengetahui tingkat keberhasilan siswa dalam menguasai materi. Hasil nilai siswa tersebut juga dijadikan sebagai indikator keberhasilan pembelajaran dengan metode eksperimen. Data nilai tes siswa pada siklus I dapat dilihat pada Tabel 2 sebagai berikut.

\begin{tabular}{cccc} 
Tabel 2 & \multicolumn{3}{c}{ Hasil Penilaian Harian IPA Siklus I } \\
\hline No. & Nilai (f) & Jumlah Siswa (x) & $\mathrm{fx}$ \\
\hline 1 & 40 & - & - \\
2 & 50 & 4 & 200 \\
3 & 60 & 12 & 720 \\
4 & 70 & 8 & 560 \\
5 & 80 & 12 & 960 \\
6 & 90 & 1 & 90 \\
7 & 100 & 1 & 100 \\
\hline Jumlah & $\mathbf{3 8}$ & 2630 \\
\hline \multicolumn{5}{c}{ Rata- rata } & & $\mathbf{6 9}$ \\
\hline Ketuntasan & $\mathbf{2 2}$ & $\mathbf{5 8 \%}$ \\
\hline
\end{tabular}

Ketuntasan siswa mengalami peningkatan yaitu menjadi 58\%. Meskipun telah mengalami peningkatan namun jumlah peningkatannya belum memenuhi indikator keberhasilan penelitian. Berdasarkan hal tersebut peneliti akan melanjutkan penelitian pada siklus II dengan metode pembelajaran yang sama yaitu metode pembelajaran eksperimen berbantu puzzle picture dengan memperbaiki kekurangan dan kelemahan yang menjadi siklus I.

Hasil pengamatan teman sejawat diperoleh hasil guru sudah baik dalam penyampaian materi, pemberiaan penguatan, melakukan tanya jawab, melaksanakan evalusi dan menganalisi evalusi. Selain itu, dalam penerapan metode eksperimen berbantu puzzle picture sudah sesuai dengan langkah pembelajaran yang direncanakan. Namun, terlihat siswa masih Kurang aktif dalam proses eksperimen tentang sistem pernapasan manusia karena hanya beberapa orang saja yang melakukan eksperimen dan permaian puzzle picture. Hal ini dikarenakan siswa kurang mendapatkan kesempatan untuk melaksanakan permainan. Berdasarkan refleksi dan hasil analisis evalusi siklus I ini, maka diperluakn upaya perbaiakan pembelajaran pada siklus II agar indikator keberhasilan penelitian dapat tercapai.

\section{Deskripsi Siklus II}

Perbaikan pembelajaran siklus II dilaksanakan pada hari Rabu, 4 September 2019. Perbaikan pembelajaran siklus II menekankan pada 1) pengefektifkan kerja kelompok dengan diskusi kelompok; 2) penggunaan puzzle picture dilaksanakan pada tiap kelompok dengan melibatkan semua anggota kelompok; dan 3) pelaksanaan eksperimen sistem pernapasan manusia oleh siswa dalam kerja kelompok tidak perwakilan siswa saja.

Adapun hasil tes evaluasi dari pelaksanaan pembelajaran pada siklus II disajikan pada Tabel 3 berikut.

Tabel 3 Hasil Penilaian Harian IPA Siklus II

\begin{tabular}{|c|c|c|c|}
\hline No. & Nilai (f) & Jumlah Siswa (x) & fx \\
\hline 1 & 40 & - & - \\
\hline 2 & 50 & - & - \\
\hline 3 & 60 & 2 & 120 \\
\hline 4 & 70 & 11 & 770 \\
\hline 5 & 80 & 13 & 1040 \\
\hline 6 & 90 & 8 & 720 \\
\hline 7 & 100 & 4 & 400 \\
\hline \multicolumn{2}{|c|}{ Jumlah } & 38 & 3050 \\
\hline \multicolumn{2}{|c|}{ Rata- rata } & & 80 \\
\hline \multicolumn{2}{|c|}{ Ketuntasan } & 36 & $95 \%$ \\
\hline
\end{tabular}

Berdasarkan data di atas, setelah menerapkan metode pembelajaran eksperimen 
berbantu puzzle picture dalam siklus II, jumlah ketuntasan siswa mengalami peningkatan yaitu menjadi $95 \%$. Sedangkan rata-rata nilai evaluasi siklus II adalah 80.

Hasil pengamatan yang dilakukan oleh teman sejawat pada pelaksanaan perbaikan pembelajaran siklus II pada guru dan siswa telah mengalami pengikatan hasil. Adapun hasil dari observasi siklus II terhadap guru secara keseluruhan guru telah melaksanakan pembelajaran dengan baik. Pada penerapan metode ekspserimen guru telah memberikan contoh melaksanakan sebuah percobaan dengan sangat baik dan memberikan contoh permainan puzzle picture dengan sangat baik. Guru mengelompokan siswa dengan baik dan memberi kesempatan siswa melakukan eksperimen sendiri. Guru memberikan pengarahan dan memberikan kesempatan untuk diskusi kepada siswa. Guru memberikan evaluasi dan menganalisis serta melaksanakan tindak lanjut evaluasi tes formatif dengan sangat baik. Hasil observasi pada siswa menunjukkan motivasi siswa dalam pembelajaran tinggi sehingga siswa lebih aktif. Selain itu, kreatifitas siswa dalam kegiatan eksperimen terlihat baik.

Dari hasil analisa siklus II ini, menunjukan siswa sudah memahami materi alat pernapasan manusia secara maksimal. Hal ini dibuktikan dengan capaian nilai mereka yang masih sudah mencapai KKM yang ditetapkan. Berdasarkan hasil siklus II penulis menghentikan penelitian tindakan sampai siklus II ini. Peningkatan hasil belajar siswa dari prasiklus, siklus I, dan siklus II dapat dilihat pada Tabel 4 berikut.

Tabel 4. Perbandingan nilai pra siklus, siklus I, dan siklus II

\begin{tabular}{ccccc}
\hline \multirow{2}{*}{ No } & \multirow{2}{*}{ Nilai } & \multicolumn{3}{c}{ Jumlah Siswa } \\
\cline { 3 - 5 } & & Pra siklus & Siklus I & Siklus II \\
\hline 1 & 40 & 4 & 0 & 0 \\
2 & 50 & 11 & 4 & 0 \\
3 & 60 & 13 & 12 & 2 \\
4 & 70 & 7 & 8 & 11 \\
5 & 80 & 3 & 12 & 13 \\
6 & 90 & 0 & 1 & 8 \\
7 & 100 & 0 & 1 & 4 \\
\hline \multicolumn{2}{c}{$\begin{array}{c}\text { Tuntas } \\
\text { belajar }\end{array}$} & $\mathbf{1 0}$ & $\mathbf{2 2}$ & $\mathbf{3 6}$ \\
\hline Rata-rata & $\mathbf{5 8}$ & $\mathbf{6 9}$ & $\mathbf{8 0}$ \\
\hline Ketuntasan & $\mathbf{2 6 \%}$ & $\mathbf{5 8 \%}$ & $\mathbf{9 5 \%}$ \\
\hline \multicolumn{2}{c}{ belajar } & &
\end{tabular}

Dari tabel diatas membuktikan nilai ratarata siswa dan persentase siswa yang tuntas belajar terus meningkat dari tiap siklus.
Walaupun tidak semua siswa tuntas belajar namun indikator keberhasilan untuk penelitian ini sudah tercapai yaitu $75 \%$ siswa tuntas belajar.

Peningkatan hasil belajar siswa dari pra siklus sampai siklus II dikarenakan penerapan metode eksperimen berbantu media puzzle picture. Penggunaan metode eksperimen dalam pembelajaran membuat siswa mengalami secara langsung dalam menemukan konsep. Menurut Subekti dan Ariswan (2016) menjelaskan bahwa dengan metode eksperimen siswa melakukan proses inkuiri untuk menemukan sebuah konsep. Ardianti (2015) juga mengungkapkan bahwa proses inkuiri dalam pembelajaran penting karena dengan penemuan konsep sendiri pembelajaran bersifat nyata dan tidak mudah terlupa oleh siswa. Penemuan konsep yang dilakukan sendiri oleh siswa secara langsung dan nyata menjadikan pembelajaran bermakna bagi siswa sehingga pembelajaran tidak hanya bersifat hafalan. Hal tersebut akan memberikan dampak pada peningkatan hasil belajar siswa. Selaras dengan pendapat Masanah (2016) bahwa penggunaan metode eksperimen dalam pembelajaran dapat meningkatkan hasil belajar siswa karena siswa dapat secara langsung melakukan sebuah percobaan untuk menemukan konsep. Metode eksperimen dapat membuat siswa membuktikan sendiri kebenaran suatu teori, sehingga akan mengubah sikap mereka yang takhayul.

Peningkatan hasil belajar siswa tidak hanya dikarenakan penerapan metode eksperimen. Penggunaan media puzzle picture juga membantu siswa dalam memahami konsep materi pembelajaran. Menurut Kristiana, dkk (2017) menjelaskan bahwa pembelajaran dengan memanfaatkan media puzzle dapat meningkatkan keaktifan dan hasil belajar siswa. Penggunaan media pembelajaran dalam pembelajaran menjadikan siswa lebih tertarik dan antuasias dalam proses pembelajaran. Selaras dengan pendapat Ardiyanti, dkk (2021) dalam penelitiannya menyebutkan bahwa adanya media pembelajaran yang digunakan akan mendukung proses pembelajaran karena dapat menumbuhkan antusias belajar siswa yang berdampak terhadap pencapaian hasil belajar siswa. Pendapat tersebut juga didukung oleh penelitian Ahmadah, dkk (2020) yang mengungkapkan bahwa penggunaan media puzzle dapat meningkatkan aktivitas belajar siswa dan berdampak terhadap peningkatan hasil belajar siswa. Penerapan metode eksperimen berbantu mendia puzzle picture terbukti membantu dapat memperbaiki kualitas pembelajaran yang ditunjukkan dengan peningkatan hasil belajar siswa. 


\section{SIMPULAN}

Penerapan metode eksperimen berbantu puzzle picture dapat meningkatkan hasil belajar siswa materi alat pernapasan manusia siswa kelas 5A semester 1 SD Negeri Bintoro 5 Kecamatan Demak Kabupaten Demak tahun pelajaran 2019/2020. Peningkatan nilai rata-rata kelas siswa pada pra siklus sebesar 58 menjadi 69 pada siklus I dan meningkat menjadi 80 pada siklus II. Persentase ketuntasan siswa juga mengalami peningkatan dari 10 siswa $(26 \%)$ pada pra siklus menjadi 22 siswa $(66 \%)$ pada siklus I dan 36 siswa (95\%) pada siklus II.

\section{DAFTAR PUSTAKA}

Ahmadah, S. N. W., Setiawan, D., \& Ardianti, S. D. Peningkatan Hasil Belajar Siswa Kelas IV Melalui Model Think Pair Share Berbantuan Media Puzzle. EduBasic Journal: Jurnal Pendidikan Dasar, 2(1), 52-60.

Ardianti, S. D. (2015). Pengaruh Modul Tematik Inquiry-Discovery Terhadap Hasil Belajar Siswa Materi Metabolisme Pembentuk Bioenergi. Refleksi Edukatika: Jurnal Ilmiah Kependidikan, 5(2).

Ardiyanti, H., Ismaya, E. A., \& Setiawan, D. (2021). Peningkatan Hasil Belajar Siswa Sekolah Dasar Dengan Penerapan Model Stad (Student Team Achievement Division) Berbantuan Media Puzzle. WASIS: Jurnal Ilmiah Pendidikan, 2(1), 29-33.

Aunurrahman. (2010), Belajar dan Pembelajaran, Bandung: Alfabeta, hal: 47, 140.

Ermida, E. (2019). dengan judul Peningkatan Prestasi Belajar IPA melalui Metode Eksperiment Learning. Jurnal Bidang Pendidikan Dasar, 3(2), 67-80

Hamdayana, J. 2017. Model dan Metode Pembelajaran Kreatif dan Berkarya. Bogor: Ghalia Indonesia.

Juita, R. (2019). Meningkatkan Hasil Belajar IPA Melalui Metode Eksperimen Pada Siswa Kelas IV SDN 02 Kota Mukomuko. IJIS Edu: Indonesian Journal of Integrated Science Education, 1(1), 43-50.

Kemmis \& Mc. Taggart. 2010. The Action Research Planner. Geelong: Deaken Univercity Press.
Kristiana, I., Nurwahyunani, A., \& Dewi, E. R. S. (2017). Pengaruh Model Pembelajaran TGT Menggunakan Media Puzzle Terhadap Keaktifan Dan Hasil Belajar Kognitif Siswa Pada Materi Sistem Ekskresi Siswa Kelas VIII MTs N 1 Semarang. Bioma: Jurnal Ilmiah Biologi, $6(2)$.

Masanah, M. (2016). Peningkatan Hasil Belajar Ipa Materi Tumbuhan Hijau Melalui Metode Eksperimen Kelas v Sdn Babadan Semester 1 Tahun Pelajaran 2015/2016. Refleksi Edukatika: Jurnal Ilmiah Kependidikan, 7(1), 22-25.

Mupelita, G. (2019). Peningkatan Hasil Belajar Siswa Melalui Penerapan Kolaborasi Media Picture Dengan Metode Eksperimen. Edutainment, 7(1), 45-60

Sagala, Syaiful. 2010. Supervisi Pembelajaran dalam Profesi Pendidikan. Bandung: Alfabeta.

Saraswati, Y. D. 2014. Preferensi Faktor-Faktor Kinerja Karyawan pada Perusahaan Daerah Air Minum (PDAM) Kabupaten Demak. Skripsi (tidak diterbitkan). Semarang: Fakultas Ekonomika dan Bisnis Universitas Diponegoro

Siti Rohana. (2011). "Metode Eksperimen Dalam Proses Pembelajaran”. Diambil dari http://blog.umy.ac.id/sitirohana/2011/12/01 /metode-eksperimendalam-prosespembelajaran/, pada tanggal 05 Juni 2012.

Subekti, Y., \& Ariswan, A. (2016). Pembelajaran fisika dengan metode eksperimen untuk meningkatkan hasil belajar kognitif dan keterampilan proses sains. Jurnal Inovasi Pendidikan IPA, 2(2), 252-261.

Sugiyono. (2014). Metode Penelitian Pendidikan Pendekatan Kuantitatif, Kualitatif, dan R\&D. Bandung: Alfabeta

Septia, S., Rahelly, Y., \& Masitoh, M. (2015). Pengaruh Permainan Puzzle Terhadap Kemampuan Mengenal Bentuk Geometri Pada Anak Kelas B1 Di TK Nurul Hidayah Palembang (Doctoral dissertation, Sriwijaya University). 
Penerapan Metode Eksperimen Berbantu Puzzle Picture Untuk Meningkatkan Hasil ... WASIS: Jurnal Ilmiah Pendidikan. Volume 2 Nomor 2 Hlm. 103-109

Syah, M., \& Ed, M. (2005). Psikologi Pendidikan Dengan Pendekatan. Bandung: PT Remaja Rosdakarya.

Tarmizi, T., Halim, A., \& Khaldun, I. (2017). Penggunaan Metode Eksperimen Untuk Mengatasi Miskonsepsi Dan Meningkatkan Pemahaman Konsep Materi Rangkaian Listrik Di Sma Negeri 1 Jaya Kabupaten Aceh Jaya, Aceh. Jurnal Pendidikan Sains Indonesia (Indonesian Journal of Science Education), 5(1), 5-11.

Widayanti, E. R., \& Slameto, S. (2016). Pengaruh Penerapan Metode Teams Games Tournament Berbantuan Permainan Dadu Terhadap Hasil Belajar IPA. Scholaria: Jurnal Pendidikan dan Kebudayaan, 6(3), 182-195. 